\title{
RECORDS OF TWO NON-MARINE SNAILS NEW FOR CROATIA (MOLLUSCA: GASTROPODA)
}

\author{
Vesna Štamol ${ }^{1}$, Rajko SlapniK ${ }^{2}$, Marijana Vuković ${ }^{1}$ \\ \& EduARD KLETEČKI ${ }^{1}$ \\ ${ }^{1}$ Croatian Natural History Museum, Demetrova 1, 10000 Zagreb, Croatia \\ ${ }^{2}$ Drnovškova pot 2, 1240 Kamnik, Slovenia
}

\begin{abstract}
Štamol, V., Slapnik, R., Vuković, M. \& Kletečki, E.: Records of two non-marine snails new for Croatia (Mollusca: Gastropoda). Nat. Croat., Vol. 24, No. 2., 337-344, Zagreb, 2015.

Literature data regarding the presence/absence of the land snail Discus rotundatus (O. F. Müller, 1774) in Croatia are discussed, occasioned by its finding on the island of Rab. A second species found on Rab, the freshwater snail Helisoma duryi (Wetherby, 1879), is recorded in this paper for the first time in Croatia.

Key words: land snails, freshwater snails, Croatia

Štamol, V., Slapnik, R., Vuković, M. \& Kletečki, E.: Nalazi dviju nemorskih vrsta puževa novih za Hrvatsku (Mollusca: Gastropoda). Nat. Croat., Vol. 24, No. 2., 337-344, Zagreb, 2015.

S obzirom na nalaz kopnenog puža Discus rotundatus (O. F. Müller, 1774) na otoku Rabu raspravljeni su literaturni podaci o njegovu postojanju/nepostojanju u Hrvatskoj. Također na otoku Rabu nađen je po prvi puta u Hrvatskoj slatkovodni puž Helisoma duryi (Wetherby, 1879).
\end{abstract}

Ključne riječi: kopneni puževi, slatkovodni puževi, Hrvatska

In the spring of 2015, specimens of non-marine snails from the island of Rab (Croatia) were sent to the first author by Mr Žarko Krstinić. The specimens turned out to belong to two species that, according to recent papers, have been considered either as non-existent in Croatia (BANK, 2007, 2010, 2013), or - for one species - as being questionable (ŠтAмоL, 2010). These are the land snail Discus rotundatus (O. F. Müller, 1774) and the freshwater snail Helisoma duryi (Wetherby, 1879).

\section{Discus rotundatus (O. F. Müller, 1774)}

Cusmich (1858) was the first to record Discus rotundatus for the area of Croatia, i.e. on the island of Lokrum (Dalmatia). However, stated that the shells were found in marine deposits. It is therefore unknown whether the specimens originated in Croatia. Marine deposits are a consequence of the southern winds and/or sea currents along the East Adriatic coast, which flow from south to north (MAGAš, 2013). Brusina (1866) mentioned Discus rotundatus in the catalogue list of the Kutschig Collection at the same locality. In those days, i.e. the time when the Kutschig Collection was formed and when the paper mentioned was written, it was seldom noted whether the material originated from such depositions. Shores of the southern Dalmatian island of Lokrum are exposed to southern winds (jugo or scirocco), and during long-lasting and strong periods of such winds, the sea deposits large amounts of floating material there. Among this material are snails 
from Montenegro, Albania and Greece. One example is the land snail Triloba sandrii (Küster, 1844), which was described from shells found in the sea deposits of the island of Lokrum and from the wider area of the nearby city of Dubrovnik (Cusmich, 1858; Brusina, 1872, 1886; BötTGER, 1878, 1879). During that time there were various theories about the actual distribution of this species (BIELz, 1866; Brusina, 1884; Letourneux, 1885; Westerlund, 1901; Brusina, 1907), but it took over 70 years to find the first living specimens. The original place of these shells turned out to be Albania (WAGNER, 1919, 1919a). It is very possible that the specimens of Discus rotundatus from the island of Lokrum in the Kutschig Collection (BRusina, 1866), as in the case of specimens of the same species from Lokrum island in the Kuzmić Collection (Cusmich, 1858) and of specimens of the mentioned Triloba sandrii from the same island (CUSMICH, 1858; BRUsiNA, 1872, 1886; BöTTGER, 1878, 1879) also originate from marine deposits. Unfortunately, no systematic research of the land snail fauna of Lokrum has been carried out that would definitely confirm or deny the existence of a living population of $D$. rotundatus. So far we do not consider the record from the cited paper (BRUSINA, 1866) to be evidence of the existence of $D$. rotundatus on Lokrum island. The real origin of specimens deposited on Lokrum is intriguing, as it was with Triloba sandrii. Discus rotundatus is not recorded in the countries south of Croatia that could be the origin of the deposited shells, namely Montenegro, Albania, or Greece (JAeckel et al., 1958; BanK, 2007, 2010, 2013; DhorA, 2014). However, it is quite likely that the species has yet to be found there. The first and so far the only definite, narrow Croatian finding sites are given by H. WAGNER (1932): Opatija and Volosko in Istria (Fig. 1).

In the malacological literature there are finding localities for Discus rotundatus for wider areas, which can only be the consequence of the generalisation of a previously published narrow locality. Still, in the 19th and the beginning of the 20th century litera-

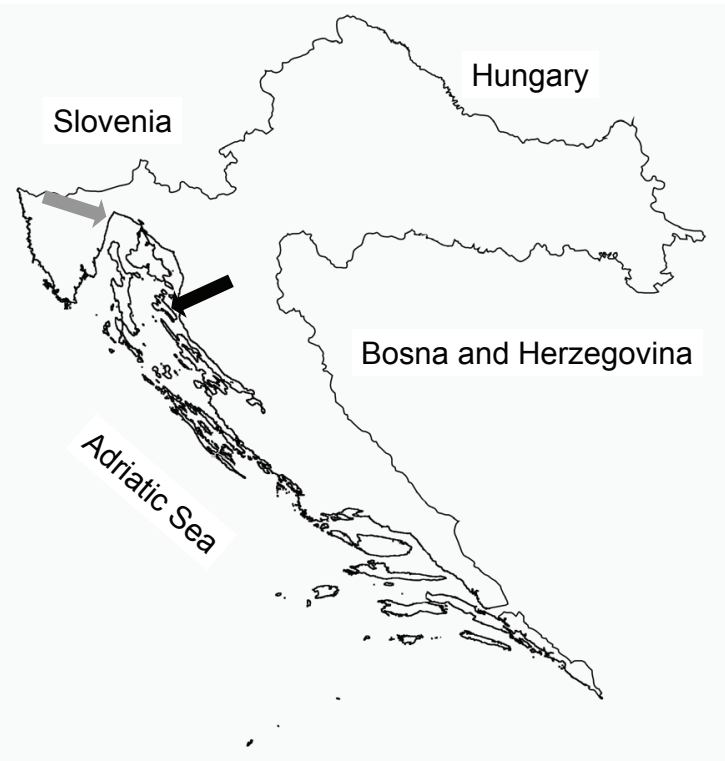

Fig. 1. Map of Croatia with positions of the island of Rab (black arrow) and of Volosko-Opatija (grey arrow). 
ture it could have happened that the first locality got denoted by a wider area, as often in KüstER (1844-1862). Wider areas that denote finding sites are:

i) former regions that are now completely within the borders of present-day Croatia, such as Slavonia, Croatia (the former Croatia, which was, along with Slavonia and Dalmatia, one of the main constituents of present-day Croatia), the Croatian Littoral - in Croatian: Hrvatsko primorje (Croatian Littoral does not encompass the entire Croatian Adriatic coast, as often incorrectly thought. According to today's understanding, it is the coastal area south of the city of Rijeka up to the river Zrmanja in the south; from the river Zrmanja and the island of Pag in the north up to the most southern part of the Croatian coast lies the area in contemporary terms regarded as Dalmatia (Borovac, 2002)). Unfortunately, literature data from this group, related to Discus rotundatus, which we should consider definitely Croatian, in these cases are questionable and cannot be taken as a proof of this species existing in Croatia. For example BIElz (1865) notes Discus rotundatus for "Kroatien und Slavonien?". From this citation we cannot conclude whether the question mark applies only to Slavonia, or to Slavonia and then Croatia. In any case, we cannot take such data as a valid proof for the species' existence in Croatia. While writing about the malacofauna of Slavonia Möllendorf[F] (1871a) cites Bielz (1865) and leaves D. rotundatus questionable for Slavonia. JAECKEL et al. (1958) list Croatia as being within its distribution area. It is not clear what the authors' reason for such statement was - it could easily have been the paper by BIELz (1865), and we consider their statement questionable.

ii) former regions only parts of which are today Croatian territories, such as i.e. Istria, Dalmatia, Illyria. If from the paper it is not undoubtedly clear that the mention of the region is a consequence of the generalisation of a Croatian locality, then such data cannot be taken as a sure proof of the existence of the species within the Croatian borders. Regarding D. rotundatus this is the case with localities labelled as Illyria (Kreglinger, 1870), Dalmatia (Kreglinger, 1870; Brusina, 1874), Dalmatia? (JAECKEL et al., 1958), Istria (BOATo et al., 1989).

iii) land units composed of former regions, some of which are completely within Croatian borders, and some only partially. Probably the most well-known and most often wrongly interpreted example is "Istrien, kroatische Littorale" in JAECKEL et al. (1958), where the Croatian Littoral, as explained before, is entirely in Croatia, while Istria is so only partly. Although in the cited paper (JAECKEL et al., 1958) "Istrien und kroat. Lit." is written once, it is given as "Istrien, kr. Lit.", and from the list of taxa, and from their distributions, the meaning of both citations is without a doubt "Istria and/or Croatian Littoral". Therefore the mentioned land unit cannot be taken as a base for proving existence of species in Croatia. Altaba (1996) gives a distribution map of Discus rotundatus in Europe and in the Mediterranean, where among other places the entire Croatian coast is marked. From the paper it is not clear on which data this distribution map is based. In recent fauna lists of Europe or its parts, Croatia is either not listed for Discus rotundatus (BANK, 2007, 2010, 2013), or its presence in Croatia is regarded as doubtful (ŠTAMOL, 2010). However, both viewpoints proved to be wrong, since exact Croatian findings for Discus rotundatus are given by H. WAGNER (1932). The finding of live specimens on the island of Rab (Kampor, edge of the Dundo forest and of Kamporsko polje field) (Fig. 1) from April, 2015, collected by Mr Žarko Krstinić, is an 
additional confirmation of the presence of Discus rotundatus in Croatia. Fortyseven specimens from this locality are deposited in the General Collection of recent molluscs of the Croatian Natural History Museum in Zagreb (Croatia).

Discus rotundatus is considered a European-Mediterranean species (Giusti et al., 1995; DALfreddo et al., 2000), emphasizing its absence from the Balkan Peninsula, Asia Minor, Middle East and Northeast Africa (Giusti et al., 1995). Within Europe its western-central European character is often emphasized (JAECKel et al., 1958; Kerney et al., 1983; Turner et al., 1998). Recently it has been recorded for the first time on the Maltese archipelago (Giusti et al., 1995), Balearic islands (Altaba, 1996), in Turkey (ÖRstan, 2003; Schütt, 2005) and in Bulgaria (Georgiev, 2014). Discus rotundatus is susceptible to passive transport by man (GIUsti et al., 1995). Uniparental reproduction in this species is possible (KuźNiK-KowalsKa, 1999), or even regular (Welter-Schultes, 2012). Thus, in favourable habitats it is easy to form and spread a population from one or only a few introduced specimens. Because of this, Discus rotundatus is not considered native in the Maltese archipelago (Giusti et al., 1995), Balearic islands (AltabA, 1996) or in Turkey (Örstan, 2003; SснÜтT, 2005). For Bulgaria its origin is not given (GEorgIev, 2014) but for this country we can conclude the same, because from the paper it could be seen that specimens were found in a habitat influenced by man (a hill in a city, and, among other things, bricks are mentioned). Discus rotundatus is also introduced in Finland (Kerney et al., 1983), and to several localities in North America, ranging from Mexico to Canada (Georgiev, 2014).

The origin of Discus rotundatus in Istria and on the island of Rab is unknown. This snail was recorded in Italy (Minelli et al., 2004; BANK, 2007, 2010, 2013) and in Slovenia (Bole, 1969; BANK, 2007, 2010, 2013), and it is very possible that its distribution is spreading from Slovenia, to the south across Istria and over the island of Rab. Still, it has not been found in areas neighbouring on or close to the island of Rab, such as on the islands of Krk (Bole, 1958), Cres (ŠTamol \& Velkovrh, 1995), Pag (Fischer et al., 2000; Reischütz \& REISCHÜTz, 2005), although systematic research has been conducted into the terrestrial malacofauna of these areas.

Because of the similarity in snail names (only the authors are different), we should mention that in the literature "Helix rotundata Drap." is mentioned for Croatia (BRusinA, 1867, 1870; MöLlendorf [F], 1871). It is interesting that Brusina $(1867,1870)$ cites Bielz, but unfortunately it is not clear which of Bielz's works is referred to. Examination of the potential source (BIELZ, 1865, 1866) established that it was not mentioned there. BRUSINA (1870) places it into group of unknown, doubtful or suspect species that have to be excluded from the Croatian fauna. The mention of Helix rotundata Drap. for Croatia in Möllendorf[F] $(1871)$ is the consequence of citing Brusina $(1867,1870)$. The authors of this paper failed to synonymise Helix rotundata Drap. with a valid species, so also not with Discus rotundatus (O. F. Müller, 1774); we suppose someone incorrectly wrote the species author's name, and it was uncritically copied by others.

\section{Helisoma duryi (Wetherby, 1879)}

The nomenclature of this species follows Welter-Schultes (2012). It should be stressed that the name Helisoma is mostly used in North American publications, whereas in most European literature the name Planorbella is used, e.g. GLÖER (2002).

Helisoma is a genus of freshwater air-breathing snails, in the family Planorbidae, which all have sinistral, or left-coiling shells. Species of the genus Helisoma are originally 
North American representatives. The species H. duryi (Wetherby, 1879) is sold in Europe for use in aquaria.

Specimens of Helisoma duryi were found for the first time living in Croatia. They were found by Mr Žarko Krstinić in the spring of 2015 in the Fruška lokva pond in the area called Fruga, between the places Supetarska Draga and Lopar on the island Rab. Seven specimens (shell height 5.6-7 mm; shell width 11-16 mm) are deposited in the General Collection of Recent Molluscs of the Croatian Natural History Museum in Zagreb (Croatia).

This species has been recorded in Europe several times. FALKnER et al. (2001, 2002) mentioned Malta and Corsica as finding places for Helisoma duryi. GLÖER (2002) mentioned for Europe 2 species belonging to the genus Helisoma: H. anceps (Menke, 1830) only from Italy (CLARKe, 1981) and H. duryi. H. duryi has further been reported from the Rhineland (Studemund \& Rosenberg, 1994), Warmbad Villach (ReIschütz, 1980), Lake Albano in Italy (Alexandrowicz, 2003; Mienis, 2004). Beckmann (2007) mentioned Mallorca, Reitano et al. (2007) mentioned Sicily, De Oliveira et al. (2010) mentioned Coimbra in Portugal. Mienis (2010, 2011) mentioned Purmerened in the Netherlands. Helisoma duryi has been also found at the inlet of a warm stream running from the UstIlimsk Pulp and Paper Plant into the Angara River in East Siberia (Sitnikova et al., 2010). In Europe the species is restricted to artificially warmed waters, and in temperate zones there are probably no permanent populations (WeLter-SCHultes, 2012).

DolENC \& JAMNIK (2009) in their study of invasive species aquarium / terrarium animals and plants in the Slovenian pet shops, recorded Helisoma in 4 aquarium shops in Slovenia. The authors stated that in Slovenia Helisoma probably does not occur in nature. In Croatia there has been no similar research. Still, it is likely that the introduction of Helisoma duryi into new habitats, including that of Rab, has come through the aquarium trade.

The number of reports of non-indigenous gastropods invading new geographical regions has greatly increased during the recent years.

Received September 14, 2015

\section{REFERENCES}

AleXandrowicz, S. W., 2003: Planorbella duryi (Wetherby, 1879) from the crater-like Albano (Central Italy). Folia Malacologica 11 (3/4), 89-93.

Altaba, C. R., 1996: Presence of Discus rotundatus (Gastropoda, Endodontidae) on the island of Mallorca. Misc. Zool. 19 (1), 51-54.

BAnk, R. A., (ed.) 2007: Mollusca, Gastropoda. Fauna Europaea version, 1.3, http://www.faunaeur.org/.

BANK, R. A., 2010: Fauna europaea project. Checklist of species-group taxa of the continental Mollusca (excl. Bivalvia) living in Albania and former Yugoslavia, Manuscript updated by Ruud A. Bank, 2512-2010.

BAnk, R. A., (ed.) 2013: Mollusca, Gastropoda. Fauna Europaea version, 2.6.2, http://www.faunaeur.org/

Beckmann, K. H., 2007: Die Land- und Susswassermollusken der balearischen Inseln. 255 pp. ConchBooks, Hackenheim.

BıELz, E. A., 1865: Systematisches Verzeichniss der Land- und Süsswasser-Mollusken des österreichischen Kaiserstaates. Verh. Mitt. siebenbürg. Ver. Naturw. Hermannstadt 16, 132-142, 158-162, 173-186, 204210, 223-234.

BıELz, E. A., 1866: Systematisches Verzeichniss der Land- und Süsswasser-Mollusken des österreichischen Kaiserstaates. Verh. Mitt. siebenbürg. Ver. Naturw. Hermannstadt 17, 14-18, 37-38, 55-58, 77-78. 
Boato, A., Bodon, M., Manuela Giovannelli, M. \& Mildner, P., 1989: Molluschi terrestri delle Alpi sudorientali. Biogeographia 13, 429-528.

Bole, J., 1958: Zoogeografski pregled malakofavne otoka Krka. Biol. vestn. 6, 118-123.

Bole, J., 1969: Ključi za določevanje živali. Mehkužci. Mollusca. 115 pp. Inštitut za biologijo Univerze v Ljubljani, Društvo biologov Slovenije, Ljubljana.

BöTtGer, O., 1878: Systematisches Verzeichniss der lebenden Arten der Landschnecken-Gattung Clausilia Drap. mit ausführlicher Angabe der geographischen Verbreitung der einzelnen Species. Bericht Offenbacher Vereins für Naturkunde 17/18, 18-101.

Boettger [Böttger], O., 1879: Gattung Clausilia. In Rossmässler, E. A. \& Kobelt, W.: Iconographie der Land- \& Süsswasser-Mollusken mit vorzüglicher Berücksichtigung der europäischen noch nicht abgebildeten Arten, 6, 52-158, Taf. 167-178, Fig. 1682-1804. C.W. Kreidels's Verlag, Wiesbaden.

Borovac, I. [ed.], 2002: Veliki atlas Hrvatske. 452 pp. Mozaik knjiga, Zagreb.

Brusina, S., 1866: Contribuzione pella Fauna dei molluschi dalmati. Verh. k. k. zool. bot. Ges. Wien 16, Beilage, 1-134.

BRusina, S., 1867: Prinesci malakologiji hrvatskoj. Rad JAZU 1, 78-105.

BRusina, S., 1870: Contribution à la malacologie de la Croatie. 40 pp. Albrecht \& Fiedler, Zagreb.

BRUsina, S., 1872: Naravoslovne crtice sa sjevero-istočne obale jadranskoga mora, sabrao god. 1868 i 1871. Dio prvi. Rad JAZU 19, 105-177.

BRusina, S., 1874: Naravoslovne crtice sa sjevero-istočne obale jadranskoga mora sabrao god. 1873. Dio drugi. Rad JAZU 27, 131-193.

BRUSINA, S., 1876: Prirodopisne znanosti osobito zoologičke u obće i kod nas. Rad JAZU 36, 35-134.

BRUsinA, S., 1884: Die Neritodonta Dalmatiens und Slavoniens nebst allerlei Malakologischen Bemerkungen (mit Tafel 2). Jahrb. Deutsch. Malakozool. Ges. 11, 17-120.

Brusina, S., 1886: Ueber die Mollusken - Fauna Oesterreich-Ungarns. Mitt. Naturw. Ver. Steiermark 22 (1885), 29-56.

BRUSINA, S., 1907: Naravoslovne crtice sa sjevero-istočne obale Jadranskoga mora. Dio četvrti i posljednji, specijalni. (Nastavak). Rad JAZU 171, Matematičko-prirodoslovni razred 42, 43-228.

Clarke, A. H., 1981: The freshwater molluscs of Canada. 46 pp. National Museum of Natural Sciences, Ottawa.

Cusmich, G., 1858: Elenco nominale degli oggetti di Storia naturale, donati sulla fine dell` anno scolastico prossimo decorso al Gabinetto ginnasiale dal Molto Reverendo Padre Maestro in farmacia Giov. Evangelista Cuzmich, dei quali nel programma dell anno passato esibile semplicemente le indicazioni numeriche sommarie. p. 85-107.

Dalfreddo, C., Giovannelli, M. M. \& Minelli, A., 2000: Molluschi terrestri e d'acqua dolce del parco nazionale Dolomiti Bellunesi. Gortania, Atti Museo Friul. di Storia Nat. 22, 117-200.

DE Oliveira, Á., Holyoak, G. A. \& Holyoak, D. T. 2010: Additional records of alien freshwater Mollusca in Portugal (Materiais para o estudo da malacofauna não-marinha de Portugal. 9). Noticiario de la Sociedad Española de Malacología 54, 41-45.

Dhora, D., 2014: Molluscs of Albania 2014: List of species and biogeographical data. Bul. Shk. Ser. Nat. 64, $149-181$.

Dolenc, B. \& JAMNIK, M., 2009: Invazivne vrste akvarijskih/terarijskih živali in rastlin v slovenskih ZOO trgovinah. Študija v sklopu projekta Tujerodne vrste - prezrta grožnja. http://www.tujerodne-vrste. info/publikacije/Zootrgovine_studija.pdf

FALKNER, G., 1990: Binnenmollusken. In: Fechter, R. \& FALKNER, G.: Weichtiere. Europaische Meeres- und Binnenmollusken. Mosaik Verlag, München, p. 112-280.

Falkner, G., Obrdlik, P., Castella, E. \& Speight, M. C. D., 2001: Shelled gastropoda of Western Europe. 267 pp. Friedrich-Held-Gesellschaft, München.

FALKNeR, G., Ripken, T. E. J. \& FalkneR, M., 2002: Mollusques continentaux de France. Liste de référence annotée et bibliographie. Collection Patrimoines Naturels 52 (1-2), 1-350.

Fischer, W., Kittel, K., Reischütz, A. \& Reischütz, P. L., 2000: Ein Beitrag zur Kenntnis der Molluskenfauna von Pag (Nord-Dalmatien, Kroatien). Nachrichtenbl. Ersten Vorarlberger Malak. Ges. 8, 53-59.

Georgiev, D., 2014: First Record of Discus rotundatus (Müller, 1774) (Gastropoda: Discidae) in Bulgaria. Acta zool. bulg. 66 (4), 575-576.

Giusti, F., Manganelli, G. \& Schembri, P. J., 1995: The non-marine molluscs of the Maltese Islands. 585 pp, 635 figg. Monografie XV, Museo Regionale di Scienze Naturali, Torino. 
GLöER, P., 2002: Die Süßwassergastropoden Nord- und Mitteleuropas. Bestimmungsschlüssel, Lebensweise, Verbreitung. Die Terwelt Deutschlands 73. 327 pp. ConchBooks, Hackenheim.

Jaeckel, S. G., Klemm, W. \& Meise, W., 1958: Die Land- und Süsswasser-Mollusken der nördlichen Balkanhalbinsel. Abh. Ber. Mus. Tierk. Dresden 23 (2), 141-205.

Kerney, M. P., Cameron, R. A. D. \& Jungbluth, J. H., 1983: Die Landschnecken Nord- und Mitteleuropas. 384 pp. Paul Parey, Hamburg und Berlin.

Kreglinger, C., 1870: Systematisches Verzeichniss der in Deutschland lebenden Binnen-Mollusken. 402 pp. C. W. Kreidel's Verlag, Wiesbaden.

Küster, H. C., 1844-1862: Die Schliessschnecken und die verwandten Gattungen (Clausilia, Balea, Cylindrella, Megaspira). In: Martini-Chemnitz: Systematisches Conchylien-Cabinet, 2, I, 14, 355 pp, 38. Taf. Bauer \& Raspe, Nürnberg.

KuźNıK-KowAlsKa, E., 1999: Life cycle and population dynamics of Discus rotundatus (O. F. Müller 1774) (Gastropoda: Pulmonata; Endodontidaea). Folia malacologica 7 (1), 5-17.

Letourneux, M. A., 1885: Étude sur la faune malacologique de la Dalmatie, de la Croatie et des contrées circonvoisines. Bull. Soc. malacolog. France 2, 195-206.

MaGAš, D., 2013: Geografija Hrvatske. 600 pp. Sveučilište u Zadru, Odjel za geografiju, Zadar; Meridijani, Samobor.

Menke, C. T., 1830: Synopsis methodica molluscorum generum omnium et specierum earum, quae in museo Menkeano adservantur; cum synonymia critica et novarum specierum diagnosibus. Editio altera, auctior et emendatior. - pp. I-XVI [=1-16], 1-168, [1]. Pyrmonti. (Uslar).

Mienis, H. K., 2004: A graveyard of Planorbella duryi forma seminole on the shores of Lake Albano, Italy. Ellipsaria 6 (3), 12.

Mienis, H. K., 2010: Planorbella duryi in a Canal in Purmerend, the Netherlands. Ellipsaria 12 (3), 9-10.

Mienis, H. K., 2011: An American Planorbid snail in a canal in Purmerend. Spirula 378, 3.

Minelli, A., Ruffo, S. \& LA Posta, S., 2004: Checklist of the species of the Italian fauna. http://www.faunaitalia.it/checklist/.

Möllendorf[F], O., 1871: Brusina's Fauna von Croatien. Nachrichtsbl. Deutsch. Malakozool. Ges. 3 (1), 20-29, (2), 40-43, (3), 62-64.

Möllendorf[F], O., 1871a: Zur Fauna von Slavonien. Nachrichtsbl. Deutsch. Malakozool. Ges. 3 (3), 6162.

Örstan, A., 2003: The first record of Discus rotundatus from Turkey. Triton 7, 27.

ReIschüтz, P., 1981: Die rezenten Wasserschnecken Österreichs (Moll., Gastropoda). Mitt. Abt. Zool. Landesmus. Joanneum 10 (2), 127-133.

Reischütz, A. \& Reischütz, P., L., 2005: Nochmals zur Molluskenfauna der Insel Pag (Nord-Dalmatien, Kroatien). Nachrichtenbl. Ersten Vorarlberger Malak. Ges. 13, 56.

Reitano, A., Liberto, F. \& Sparacio, I., 2007: Nuovi dati su molluschi terrestri e dulciacquicoli di Sicilia. $1^{\circ}$ Contributo (Gastropoda Prosobranchia Neotaenioglossa; Gastropoda Pulmonata Basommatophora, Stylommatophora). Naturalista siciliano, S. IV, XXXI (3-4), 311-330.

Sснӥтт, H., 2005: Turkish Land Snails. 4th, revised and enlarged edition. 559 pp. Verlag Natur \& Wissenschaft, Solingen [Deutschland].

Sitnikova, T., Soldatenko, E., Kamaltynov, R. \& Riedel F., 2010: The finding of North American freshwater gastropods of the genus Planorbella Haldeman, 1842 (Pulmonata: Planorbidae) in East Siberia. Aquatic Invasions 5 (2), 201-205.

Studemund, A. \& Rosenberg, J., 1994: Freilandvorkommen von Melanoides tuberculatus (O. F. Müller 1774) und Planorbella duryi (Wetherby, 1879) im Rheinland nebst Anmerkungen zu Hydropsyche exocellata (Dufour 1841) (Trichoptera: Hydropsychidae). Mitt. dtsch. malak. Ges. 53, 15-18.

Šтамоl, V., 2010: A list of the land snails (Mollusca: Gastropoda) of Croatia, with recommendations for their Croatian names. Nat. Croat. 19 (1), 1-76.

Štamol, V. \& Velkovrh, F., 1995: Contribution to the knowledge of land snail fauna of the islands of Cres and Lošinj (Croatia) (Gastropoda: Prosobranchia, Basommatophora, Stylommatophora). Malak. Abh. Mus. Tierkd. Dresden 17 (20), 219-237.

Turner, H., Kuiper, J. G. J., Thew, N., Bernasconi, R., Rüetschi, J., Wüthrich, M. \& Gosteli, M., 1998 : Fauna Helvetica 2. Atlas der Mollusken der Schweiz und Liechtensteins. 527 pp. Centre suisse de cartographie de la faune, Schweizerische Entomologische Gesellschaft, Eidg. Forschungstalt für Wald, Schnee und Landschaft, Neuchâtel, Suisse. 
Wagner, A. J., 1919: Beschreibungen neuer oder bisher wenig bekannter Clausiliiden (I. Teil). Anzeiger Akademie der Wissenschsften in Wien, Mathematisch-naturwissenschaftliche Klasse 56 (4), 57-64.

Wagner, A. [J.], 1919a: Zur Anatomie und Systematik der Clausiliiden. Nachrichtsbl. Deutsch. Malakozool. Ges. 51 (2), 49-60, (3), 87-104, (4), 129-147.

Wagner, H., 1932: Weitere Mitteilungen über die Molluskenfauna von Abbazia und Umgebung. Atti Real. Ist. Veneto sci. lett. art. 91 (2), 729-736.

Welter-Schultes, F. W, 2012: European non-marine molluscs, a guide for species identification. A1-A3, 679, Q1-Q78 pp. Planet Poster Editions, Göttingen.

Westerlund, C. A., 1901: Synopsis molluscorum in regione palaearctica viventium ex typo Clausilia Drap. Mém. Acad. Impér. Sci. St. Pétersbourg, VIII Sér., Classe Physico-math., 11 (11), I-XXXVII, 1-203.

Wetherby, A. G., 1879. Notes on some new or little known North American Limnæidæ. Journal of the Cincinnati Society of Natural History 2 (2), 93-100. 